\title{
Essential amino acid supplementation in patients with severe COPD: a step towards home rehabilitation
}

\author{
R.W. Dal Negro1,2, †A. Testa3, R. Aquilani4, S. Tognella1, \\ E. Pasini 5 , A. Barbieri6, F. Boschi6
}

ABSTRACT: Essential amino acid supplementation in patients with severe COPD: a step towards home rehabilitation. R.W. Dal Negro, A. Testa, R. Aquilani, S. Tognella, E. Pasini, A. Barbieri, F. Boschi.

Background. Pulmonary Rehabilitation ("Rehabilitation") can improve both lung function and quality of life in patients suffering from chronic obstructive pulmonary disease (COPD) even if only a very small proportion of patients have access to Rehabilitation.

Supplementation of Essential Amino Acids (EAAs) might allow COPD patients to achieve some typical Rehabilitation outcomes such as a better physical performance and an improved health status.

Methods. 88 COPD out-patients (GOLD class 3-4) with a body mass index $(\mathrm{BMI})<23 \mathrm{Kg} / \mathrm{m}^{2}$ were randomised to receive EAAs $(n=44)$ or placebo $(n=44)$ for twelve weeks.

Primary outcome measures were changes in both physical activities in daily life (measured by Sense Wear Armband in terms of mean steps walked in one week) and in quality of life (measured by the St George's Respiratory Questionnaire, SGRQ).
Results. After 12 weeks, the physical performance was significantly increased $v$ s baseline only in patients who received EAAs $(1140.33 \pm 524.69$ and $638.68 \pm 662.1$ steps/day, respectively; $p=0.02$ ), being also the comparison vs the placebo group highly significant $(p=0.003)$. Similarly, the SGRQ score improved significantly only in EAA patients $(69.35 \pm 9.51$ vs baseline $72.04 \pm 8.62 ; p<0.01)$, and changes were significantly different from those measured in the placebo group $(p<0.001)$. Furthermore, when compared to those who received placebo, EAAs patients significantly increased their fat-free mass $(p=0.04)$, muscle strength $(p<0.01)$, saturation of oxygen $(p=0.05)$, serum albumin $(p<0.001)$, and also ameliorated their original cognitive dysfunction $(\mathrm{p}=0.02)$.

Conclusions. Oral supplementation with EAAs contribute to improve the daily-life performance in domiciliary severe COPD patients who can not enter any Rehabilitation programme, together with their quality of life; nutritional and cognitive status, and muscle strength.

Monaldi Arch Chest Dis 2012; 77: 2, 67-75.

Keywords: Essential Amino Acids, COPD, Sarcopenia, Physical performance.

1 U.O.C. di Pneumologia, ULSS22 Regione Veneto, Ospedale Orlandi, Bussolengo, Verona;

2 Centro Nazionale Studi di Farmacoeconomia e Farmacoepidemiologia Respiratoria, Verona;

3 Riabilitazione CardioPneumologica Ospedale Ettore Spalenza, Fondazione Don Gnocchi, Rovato, Brescia;

4 Servizio di Fisiopatologia Metabolico-Nutrizionale e Nutrizione Clinica, Fondazione S. Maugeri, IRCCS, Istituto Scientifico di Montescano, Pavia;

5 Fondazione S. Maugeri, IRCCS, Istituto Scientifico di Lumezzane, Brescia;

6 Dipartimento di Scienze del Farmaco, Università degli Studi di Pavia, Pavia, Italy.

Correspondence: Dr. Federica Boschi, Dipartimento di Scienze del Farmaco, Università degli Studi di Pavia, Viale Taramelli 12,27100 Pavia, Italy; e-mail:federica.boschi@unipv.it

\section{Introduction}

Chronic Obstructive Pulmonary Disease (COPD) has a great medical and social impact on public health in Italy as at least $10 \%$ of general population is affected by COPD [1]; more than $15 \%$ of these subjects is suffering from severe COPD [2], and they presumably are living in disabled conditions.

Pulmonary Rehabilitation (Rehab) is a consolidate interventional strategy that can contribute to control and alleviate symptoms; optimize functional capacity [3]; recover lung function and quality of life as much as possible [4], and reduce rehospitalisation due to exacerbations [5]. Rehab al- so proved cost effective [6]. However, despite these favourable outcomes, the prevalence of COPD patient who attend Rehab centres or undergo any Rehab protocol is not known. No national data is available in Italy, but it is presumed that the vast majority of COPD patients are excluded from Rehab in our country. This would suggest the need for other feasible treatments which, in the absence of Rehab, could however surrogate some relevant Rehab's benefits to these patients to.

For the present study, it has basically been hypothesised that essential amino acid (EAA) supplementation could allow patients with COPD to achieve two strong rehab outcomes just at home, such as an improved physical activity and a better 
quality of life [3]. This hypothesis relies on the following considerations: firstly, EAAs, by promoting protein synthesis [7], can increase body mass (mainly the muscle portion) which plays a crucial role for the exercise performance and the perception of well-being. Secondly, preliminary studies carried out by two independent groups $[8,9]$ have shown that EAA supplementation increases physical activity, cognition and quality of life in cachectic/sarcopenic COPD subjects, while another study found that EAAs can improve the nutritional state; the muscle metabolism, and the exercise capacity in individuals with chronic heart failure [10]. Furthermore, several studies found that EAAs work as precursors in the synthesis of brain neurotransmitters [11] which are involved in mood, behavioural motor activity, and cognition [12].

Therefore the effects of EAAs on physical performance and quality of life of sarcopenic patients with severe COPD living at home were investigated.

\section{Methods}

\section{Patients}

Eighty-eight outpatients with stable, severe COPD (GOLD class 3-4) were selected from those regularly attending our Units and enrolled according to a randomised, double-blind, parallel groups design.

Patients were selected on the basis of the following criteria: 1 . never admitted to any Rehab programme; 2 . daily energy $\geq 28 \mathrm{Kcal} / \mathrm{Kg}$, and protein intake $\geq 1 \mathrm{~g} / \mathrm{Kg}$; 3 . age $>40$ yrs, and body weight stable $\pm 1 \mathrm{Kg}$ over the last six months; 4. body mass index $(\mathrm{BMI})<23 \mathrm{Kg} / \mathrm{m}^{2} ; 5$. baseline post-bronchodilator $\mathrm{FEV}_{1}$ (forced expiratory volume in $1 \mathrm{sec})<50 \%$ predicted; $6 . \mathrm{FEV}_{1}$ reversibility $<12 \%$ from baseline after salbutamol $400 \mathrm{mcg}$; 7. $\mathrm{FEV}_{1} / \mathrm{FVC}$ (forced vital capacity) $<70 \%$.

Exclusion criteria were: age $<40$ yrs; postbronchodilator $\mathrm{FEV}_{1}>50 \%$ predicted; $\mathrm{FEV}_{1} / \mathrm{FVC}$ $>70 \%$; $\mathrm{FEV}_{1}$ reversibility $>12 \%$ from baseline after salbutamol $400 \mathrm{mcg}$; $\mathrm{BMI}>23 \mathrm{Kg} / \mathrm{m}^{2}$; any mental deterioration severely affecting the adherence to protocol procedures and treatment assumption; the occurrence of acute exacerbation of COPD in the last four weeks; diabetes; heart failure; endocrine disorders, and neoplasms.Patients were regularly assuming respiratory drugs since long time (Long-acting antimuscarinic - LAMA; long-acting $\beta_{2}$ adrenergics - LABA, inhaled corticosteroids - ICS).

All participants were fully informed about the nature of the study and gave their written consent, with approval of local technical ethics committee.

\section{The supplementation protocol}

An oral mixture of essential amino acid (EAAs) (table 1) was the active treatment, while the control treatment was an isocaloric placebo.

Subjects were randomised to receive $4 \mathrm{~g}$ of EAAs bid $(n=44)$ or an undistinguishable dose of placebo $(n=44)$ at $10: 00$ am and 5:00 pm, for 12week. The oral EAAs mixture (Aminotrofic) was manufactured by Professional Dietetics, Milan, Italy. Investigators were blinded to the randomisation table, the code assignments, and the procedure. As subjects were enrolled, they were assigned a progressive number.

Safety was also checked during the study by monitoring the occurrence of serious side effects (i.e., gastrointestinal symptoms, such as abdominal pain; nausea, or diarrhoea).

The use of respiratory drugs was comparable in the two groups, and LAMA was equally prevailing in both groups (68.2 and $70.4 \%$, respectively).

One week before, and after 4 and 12 weeks of the protocol patients underwent the following procedures, after overnight fasting, at 8-10 am:

1. the physical activity: the daily ambulation during the patients' free time at home was measured by using the Sense Wear Armband Pro3 (Body Media; Pittsburgh, PA, USA) placed on the upper right arm of each patient and continuously worn for one week. Armbands consented to estimate the energy expenditure (Kcal) during the daily life by using an accelerometer, together to non-invasive physiological measures [13]. The numbers of steps performed over one week were divided by seven to obtain the average number of steps daily walked and the corresponding energy expenditure;

2. the health status: the St George's Respiratory Questionnaire (SGRQ) was chosen to measure the disease-specific health status because it is reproducible and specific for respiratory patients. Briefly, the SGRQ investigates three main domains including symptoms (distress from respiratory symptoms); activity and impact on daily life and wellbeing. We calculated the sum of the single partial scores in order to obtain a total score up to 100 points; higher the score, higher the impairment of the patient's health status.

As both the physical performance and the quality of life, which are mutually interdependent, depend on several factors including the body composition $[14,15]$; the nutritional intake, the muscle

Table 1. - Amino acid composition of an individual packet containing $4 \mathrm{~g}$ of the mixture used in this study

Kcal

Total aminoacids of which

L-Leucine

L-Lysine

L-Isoleucine

L-Valine

L-Threonine

L-Cysteine

L-Histidine

21.9

L-Phenylalanine

L-Methionine

L-Tyrosine

L-Tryptophan

$4 \mathrm{~g}$

$1250 \mathrm{mg}$

$650 \mathrm{mg}$

$625 \mathrm{mg}$

$625 \mathrm{mg}$

$350 \mathrm{mg}$

$150 \mathrm{mg}$

$150 \mathrm{mg}$

$100 \mathrm{mg}$

$50 \mathrm{mg}$

$30 \mathrm{mg}$

$20 \mathrm{mg}$ 
strength and metabolism; the arterial blood gas tensions, saturation of oxygen and the cognitive status, also the following variables were measured:

- the body weight and height, and the body mass index $(\mathrm{BMI})\left(\mathrm{Kg} / \mathrm{m}^{2}\right)$ was calculated;

- $\quad$ the body composition was measured by means of single-frequency bio-impedance analysis (BIA; 50 Hz; TANITA BC-420 MA; TANITA CORP, Tokyo Japan) with participants in a supine position. The fat-free mass (FFM) was calculated by using the COPD-specific equation, while the fat mass (FM) was calculated as the difference between the total body weight and the FFM. BIA was extensively validated in patients with COPD. BIA measurements were performed by the same trained authors.

FFM and FM were expressed in $\mathrm{Kg}$ and as $\mathrm{Kg} /$ height-squared (FFMI) [16], i.e. lean body mass index (LBMI).

FFMI $<16 \mathrm{Kg} / \mathrm{m}^{2}$ in men and FFMI $<15$ $\mathrm{Kg} / \mathrm{m}^{2}$ in women were assumed as indicators of a low FFMI [17] and sarcopenia;

- the nutritional intake was measured by means of a 3-day food diary [18]. Each patient was asked to keep a food diary at home for 3 consecutive days to fill before and after meals in order to register both the kind and the weight of cooked or uncooked food assumed. We converted this data to raw equivalents by using appropriate table when necessary [19].

Patients became accustomed to keeping a nutritional diary as an essential part of their clinical control over time. Moreover, patients were regularly reminded of the importance of keeping an accurate diary for this study. The principal investigator was responsible for keeping the patients informed; for checking the food diaries, and for calculating nutritional intakes (via a computerized system set up by our group) [20]. Energy (Kcal) and macronutrient intake (carbohydrates, proteins, and lipid expressed in g) were also related to the patient' body weight $(\mathrm{Kg})$;

- the muscle strength: this function was measured by means of an hydraulic hand dynamometer Jamar (Sammons Preston Rolyan, Bolingbrook, Canada) as it measures quantitatively the muscle function in different joints [21]. Both hands were tested three times, and the best results for each hand was used for comparing the effect of treatments. All measurement were performed in the morning (between 8:00-10:00 am), in the sitting position, and with the arm held in a comfortable position as described by Spijkerman et al. [22];

- the muscle metabolism: lactate plasma concentration of [23] ( $\mu \mathrm{mol} / \mathrm{l})$ was measured in all patients in peripheral venous blood samples, its increase mirroring the enhancement of the muscle anaerobic pathway, such as a reduced activity of the aerobic cycle for energy formation;

- the cognitive function: patients' cognition was measured by means of the Mini Mental State Examination (MMSE) [24]; the range of the score is 0 (maximal cognitive dysfunction) -
30 (optimal cognitive function), while a score $>24$ denotes a normal cognitive function;

- blood gas tensions: arterial oxygen $\left(\mathrm{PaO}_{2}\right.$, $\mathrm{mmHg})$ and carbondioxide $\left(\mathrm{PaCO}_{2}, \mathrm{mmHg}\right)$ partial pressures were measured (ABL 735 analyser, Radiometer, Copenhagen, DK) in blood samples drawn anaerobically from the left radial artery.

\section{Statistics}

Descriptive statistics (mean \pm standard deviation) were calculated for all variables. The unpaired Student's $t$ test was used for comparing basic data of the EAA supplemented group vs those with placebo. The analysis of variance for repeated measures was used to evaluate the trends for all variables over time. Statistical significance was expressed as the value of the time group interaction, testing the various trends between patient belonging to the placebo or to the EAA group. A significance level of $\mathrm{p}<0.05$ was accepted.

\section{Results}

\section{Baseline characteristics}

The two groups of patients were comparable in terms of body weight; body composition; lung function; muscle metabolism; physical activity; level of cognitive dysfunction, and perception of their health status (table 2). Nutritional intake (table 3); muscle strength, and energy expenditure for ambulation (table 4) were also similar in the two groups.

According to the inclusion criteria, all patients were sarcopenic (LBMI $<16 \mathrm{Kg} / \mathrm{m}^{2}$ in men, $<15$ $\mathrm{Kg} / \mathrm{m}^{2}$ in women).

Patients had a reduced muscle strength together an increased anaerobic metabolic pattern as indicated by the elevated levels of plasma lactate which corresponds to $\geq 8$-fold the average limit of normal values. Liver capacity for protein synthesis was significantly lowered, thus leading to mild hypoalbuminemia.

An important reduction of physical activity was also found. The patients' walking capacity was slightly higher than 600 steps/day. It was calculated that the energy expenditure normalized for FFM was similar in the two groups $(1.27 \pm 0.59$ $\mathrm{Kcal} / \mathrm{Kg}$ FFM in placebo patients vs $1.3 \pm 0.75$ in treated ones) during ambulation. Finally, patients showed an altered cognition and a poor perception of their health status and quality of life.

In other words, in basal conditions, severe COPD patients recruited were in stable condition and sarcopenic; had an equivalent nutritional intake, and were characterized by an impaired muscle strength; an increased anaerobic metabolism; a substantial reduction of their daily physical; cognitive performances, and quality of life.

\section{Variables at three months}

After 12 weeks of treatment, only patients EAAs supplemented, but not those assuming placebo, improved significantly their body weight $(+5.53 \pm 3.47 \mathrm{Kg} ; \mathrm{p}=0.001) ; \mathrm{LBMI}\left(+1.34 \mathrm{Kg} / \mathrm{m}^{2}\right.$ $\pm 0.29 ; \mathrm{p}=0.06)$ : muscle strength $(+1.6 \mathrm{Kg} \pm 0.24$; $\mathrm{p}=0.05)$; saturation of oxygen $(+4.75 \mathrm{mmHg} \pm$ 2.61; $\mathrm{p}=0.03)$; physical activity $(+502$ steps, 
Table 2. - Variables measured in the two groups of patients after randomization to placebo or EAAs supplementation, and their statistical comparison (t test)

\begin{tabular}{|c|c|c|c|c|}
\hline Variables & nv & Placebo group & EAAs supplemented group & $p$ value \\
\hline \multicolumn{5}{|l|}{ Demographic } \\
\hline Male/Female & - & $29 / 15$ & $32 / 12$ & ns \\
\hline Age (years) & - & $73 \pm 8$ & $75 \pm 5$ & ns \\
\hline \multicolumn{5}{|l|}{ Anthropometric } \\
\hline $\mathrm{BW}(\mathrm{Kg})$ & - & $54.3 \pm 7$ & $53.32 \pm 6.74$ & 0.7 \\
\hline BMI $\left(\mathrm{Kg} / \mathrm{m}^{2}\right)$ & - & $20.1 \pm 2$ & $19.95 \pm 1.63$ & 0.9 \\
\hline LBMI $\left(\mathrm{Kg} / \mathrm{m}^{2}\right)$ & - & $14.8 \pm 2.3$ & $15.18 \pm 2.22$ & 0.6 \\
\hline \multicolumn{5}{|l|}{ Body composition } \\
\hline FFM (Kg) & - & $35.80 \pm 5$ & $40.2 \pm 4.23$ & 0.8 \\
\hline $\mathrm{FM}(\mathrm{Kg})$ & - & $14.9 \pm 2.5$ & $14 \pm 2.4$ & 0.7 \\
\hline \multicolumn{5}{|l|}{ Serum protein } \\
\hline Total proteins $(\mathrm{g} / \mathrm{l})$ & $65-80$ & $61.46 \pm 5.25$ & $61.95 \pm 2.86$ & 0.9 \\
\hline Albumin (g/l) & $35-50$ & $33.05 \pm 2.91$ & $32.73 \pm 3.97$ & 0.7 \\
\hline \multicolumn{5}{|l|}{ Pulmonary function } \\
\hline $\mathrm{FEV}_{1}(\mathrm{l} / \mathrm{sec})$ & - & $0.8 \pm 0.2$ & $0.79 \pm 0.42$ & 0.4 \\
\hline $\mathrm{FEV}_{1} / \mathrm{FVC}(\%)$ & - & $37.7 \pm 11.59$ & $39.49 \pm 7.47$ & 0.7 \\
\hline \multicolumn{5}{|l|}{ Blood gas tension } \\
\hline $\mathrm{PaO}_{2}(\mathrm{mmHg})$ & $80-100$ & $60.09 \pm 5.01$ & $61.45 \pm 8.7$ & 0.6 \\
\hline $\mathrm{PaCO}_{2}(\mathrm{mmHg})$ & $35-45$ & $46.1 \pm 8$ & $45.30 \pm 7$ & 0.7 \\
\hline \multicolumn{5}{|l|}{ Oxygen saturation } \\
\hline $\mathrm{HbO}_{2}(\%)$ & - & $94.28 \pm 0.1$ & $94.48 \pm 2.16$ & 0.9 \\
\hline \multicolumn{5}{|l|}{ Muscle metabolism } \\
\hline Plasma lactate $(\mu \mathrm{mol} / \mathrm{l})$ & $0.2 \pm 0.15$ & $1.7 \pm 0.3$ & $1.52 \pm 0.83$ & 0.7 \\
\hline \multicolumn{5}{|l|}{ Daily walking } \\
\hline Steps $\left(\mathrm{n}^{\circ}\right)$ & - & $609.70 \pm 454.80$ & $638.68 \pm 662.1$ & 0.9 \\
\hline \multicolumn{5}{|l|}{ Cognitive function } \\
\hline MMSE (score) & $\geq 24$ & $20.8 \pm 3.72$ & $18.92 \pm 4.8$ & 0.5 \\
\hline \multicolumn{5}{|l|}{ Health status } \\
\hline SGRQ (score) & - & $71.31 \pm 7.28$ & $72.04 \pm 8.62$ & 0.8 \\
\hline
\end{tabular}

Data are expressed as mean \pm standard deviation (SD).

Statistical analysis: Student's t test for unpaired data; placebo group vs EAAs supplemented group.

$\mathrm{BW}=$ body weight; $\mathrm{BMI}=$ Body Mass Index; LBMI = Lean Body Mass Index, FFM = fat-free mass; FM = fat mass; FEV F $_{1}$ forced expiratory volume1; $\mathrm{FVC}=$ forced vital capacity; $\mathrm{PaO}_{2}=$ partial pressure of oxygen; $\mathrm{PaCO}_{2}=$ Partial pressure of carbon dioxide; $\mathrm{HbO}_{2}=$ oxygen saturation; $\mathrm{MMSE}=$ Mini Mental State Examination test; SGRQ = St.George's Respiratory Questionnaire.

$\mathrm{nv}=$ normal value; $\mathrm{ns}=$ not significant.

$+56 \% ; \mathrm{p}=0.02)$; serum total protein concentration $(\mathrm{p}=0.05)$; cognitive dysfunction $(\mathrm{p}=0.02)$, and quality of life $(\mathrm{p}<0.01)$.

Moreover, significant differences between the two groups were also proved in terms of body weight $(p=0.005)$; FFM ( $\mathrm{p}=0.04)$; muscle strength $(\mathrm{p}<0.01)$; saturation of oxygen $(p=0.05)$; serum albumin $(p<0.001)$; cognitive function $(\mathrm{p}=0.02)$; quality of life $(p<0.001)$; physical performance $(p=0.003)$, and energy expenditure for ambulation $(p<0.001)$ (table 4).

\section{Discussion}

Data from the present study indicates that sarcopenic, severe COPD subjects can obtain even at home some substantial rehab outcomes (i.e the improvement in their physical activity and quality of life) if supplemented uniquely with EAAs.

Though physical activity and quality of life are strictly linked [25] and mutually affecting each other [25], EAAs may separately affect each of them. 
a) EAAs and physical activity

The patients enrolled in the present study originally had a very sedentary life style [26]. The improvement in daily physical activity following EAA supplementation was likely due to a substrate-associated improvement of body weight and composition [14, 15, 27]; muscle strength; muscle energy metabolism; muscle and systemic acidosis, and saturation of oxygen.

The gain in body weight, and mainly in FFM, was probably due to EAA stimulation of muscle protein synthesis. This overall metabolic orientation is also suggested by the increased serum albumin level which mirrors the enhanced protein synthesis occurring in the liver. Both the increased body weight/FFM and albumin synthesis cannot be referred to a better dietary intake because the latter did not change over time and was quite similar in the two groups.

Since low oxygen tensions stimulate the production of tumour necrosis factor [28, 29] which affects (such as reduces) albumin synthesis, an improved oxygen tension can likely contribute to increase body weight/composition and albumin, even though data of the present study does not provide any definitive explanation of the improved saturation of oxygen. It is also presumable that an ameliorated cardiac performance associated with EAAs supplementation [30] could improve the blood distribution throughout the different pulmonary regions. The mechanisms by which EAAs stimulate the FFM growth are both direct and indirect. Direct, because EAAs stimulate the protein synthesis [31] and inhibit proteolysis at the same time [32]. Indirect, because EAAs boost protein formation by inducing protein production, and also increase the biological activity of insulin-like growth factor (IGF-I) [33]. The documented evidence that a three-month supplementation of 7.5 g/day of EAAs in older women increases base IGF-I expression [34] supports this hypothesis.

The independence of EAAs activity from insulin [35] is particularly valuable for those COPD patients who are insulin resistant or have reduced their levels of circulating anabolic hormones [36].

Changes in body composition observed in the present study following EAAs vary quantitatively and qualitatively from previous researches. Actually, the observed increase in body weight $(+5.53$ $\mathrm{Kg})$ and in FFM $(+3.66 \mathrm{Kg})$ following EAAs proved higher than those obtained in COPD patients after an 8-week program consisting of nutritional supplementation combined with intensive Rehab [37]. While changes in body composition mainly consisted of increased FFM with EAAs, megestrol administration mainly induced a FAT mass increase [38]. Moreover, the tissue increase was not due to a higher nitrogen intake from EAAs because total (diet + supplementation) nitrogen intake $[10 \mathrm{~g})$ in treated subjects was equal to that of patients assuming placebo.

The muscle strength is a major determinant of physical activity; so, the improved physical performance in the EAAs group was also due to improved muscle strength.

The significant reduction in basal hyperlactatemia after EAAs treatment [28, 29, 39-42] is another important factor further contributing to a better exercise tolerance for at least three reasons. First, the diminution of blood hydrogenions reduces the excess of ventilation particularly during the physical effort. Secondly, reduced lactate formation suggests increased efficiency and efficacy of aerobic production; this is also supported by the

Table 3. - Daily nutritional intakes in the two groups of patients in baseline and after the 12-week supplementation

\begin{tabular}{|c|c|c|c|c|c|c|}
\hline \multirow[b]{2}{*}{ Daily nutritional intake } & \multirow[t]{2}{*}{ nv } & \multicolumn{2}{|c|}{ Placebo group $(n=)$} & \multicolumn{2}{|c|}{ EAA supplemented group $(n=)$} & \multirow[t]{2}{*}{ p value } \\
\hline & & baseline & after 12 weeks & baseline & after 12 weeks & \\
\hline \multicolumn{7}{|l|}{ Energy } \\
\hline Kcal & - & $1650 \pm 275$ & $1701 \pm 325$ & $1590 \pm 195$ & $1610 \pm 203$ & ns \\
\hline $\mathrm{Kcal} / \mathrm{Kg}$ & $\geq 25$ & $30.3 \pm 5.02$ & $30.5 \pm 6.2$ & $29.7 \pm 3.6$ & $29.9 \pm 4.1$ & ns \\
\hline \multicolumn{7}{|l|}{ Proteins } \\
\hline $\mathrm{g}$ & - & $59.8 \pm 7.5$ & $61.3 \pm 8.1$ & $54.5 \pm 9.6$ & $55 \pm 10.1$ & $\mathrm{~ns}$ \\
\hline $\mathrm{g} / \mathrm{Kg}$ & $\geq 1$ & $1.1 \pm 0.14$ & $1.15 \pm 0.18$ & $1.02 \pm 0.18$ & $1.02 \pm 0.2$ & ns \\
\hline$\% \mathrm{E}$ & - & $14.5 \pm 1.8$ & $14.4 \pm 2.1$ & $13.7 \pm 2.4$ & $13.7 \pm 2.5$ & ns \\
\hline \multicolumn{7}{|l|}{ Lipids } \\
\hline $\mathrm{g}$ & - & $55.8 \pm 9.5$ & $59.1 \pm 10.1$ & $59.1 \pm 12.3$ & $59.2 \pm 13$ & \\
\hline $\mathrm{g} / \mathrm{Kg}$ & $\leq 1$ & $1.02 \pm 0.17$ & $1.06 \pm 0.2$ & $1.1 \pm 0.22$ & $1.1 \pm 0.19$ & ns \\
\hline$\% \mathrm{E}$ & - & $30.4 \pm 5.2$ & $31.3 \pm 6.5$ & $33.4 \pm 7.0$ & $33 \pm 7.5$ & ns \\
\hline \multicolumn{7}{|l|}{ Carbohydrates } \\
\hline $\mathrm{g}$ & - & $277 \pm 35$ & $231 \pm 40$ & $210 \pm 51$ & $213 \pm 60$ & ns \\
\hline $\mathrm{g} / \mathrm{Kg}$ & $2.5-4$ & $4.17 \pm 0.64$ & $4.2 \pm 0.71$ & $3.92 \pm 0.98$ & $3.93 \pm 1.01$ & ns \\
\hline$\% \mathrm{E}$ & - & $55 \pm 8.5$ & $54.3 \pm 8.9$ & $52.8 \pm 12.8$ & $52.9 \pm 13.1$ & ns \\
\hline
\end{tabular}

Data are expressed as mean \pm standard deviation (SD).

Statistical analysis: Anova testplacebo group vs EAA supplemented group.

$\mathrm{nv}=$ normal value; $\mathrm{ns}=$ not significant. 
Table 4. - Changes over time of the measured variables. Mean $\pm S D$ and statistical analysis between placebo and EAAs supplemented patients

\begin{tabular}{|c|c|c|c|c|c|c|c|c|c|}
\hline Variables & Plac & ebo group & & & EA & A group & & & nteraction \\
\hline & & & $\mathrm{T} 4 v s \mathrm{~T} 0$ & $\mathrm{~T} 12$ vs $\mathrm{T} 0$ & & & $\mathrm{~T} 4$ vs $\mathrm{T} 0$ & $\mathrm{~T} 12$ vs $\mathrm{T} 0$ & \\
\hline $\mathrm{PaCO}_{2}(\mathrm{mmHg})$ & $\begin{array}{l}\text { T } 0 \\
\text { T } 4 \\
\text { T } 12\end{array}$ & $\begin{array}{l}46.1 \pm 8 \\
46.19 \pm 4 \\
45.41 \pm 5\end{array}$ & ns & ns & $\begin{array}{l}\text { T } 0 \\
\text { T } 4 \\
\text { T } 12\end{array}$ & $\begin{array}{c}45.30 \pm 7 \\
46.19 \pm 6.22 \\
45.87 \pm 4.74\end{array}$ & ns & $\mathrm{p}=0.5$ & $\mathrm{p}=0.6$ \\
\hline $\mathrm{PaO}_{2}(\mathrm{mmHg})$ & $\begin{array}{ll}\text { T } 0 \\
\text { T } 4 \\
\text { T } 12 \\
\end{array}$ & $\begin{array}{c}60.09 \pm 5.01 \\
58 \pm 4.98 \\
57 \pm 4.50 \\
\end{array}$ & $\mathrm{~ns}$ & $\mathrm{~ns}$ & $\begin{array}{ll}\text { T } & 0 \\
\text { T } 4 \\
\text { T } 12 \\
\end{array}$ & $\begin{array}{c}61.45 \pm 8.7 \\
62.09 \pm 6.48 \\
66.20 \pm 6.09 \\
\end{array}$ & ns & $\mathrm{p}=0.03$ & $\mathrm{p}=0.05$ \\
\hline $\mathrm{sO}_{2}(\%)$ & $\begin{array}{l}\text { T } 0 \\
\text { T } 4 \\
\text { T } 12\end{array}$ & $\begin{array}{c}94.28 \pm 0.1 \\
94 \pm 1.77 \\
94.8 \pm 1.8\end{array}$ & $\mathrm{~ns}$ & ns & $\begin{array}{l}\text { T } 0 \\
\text { T } 4 \\
\text { T } 12\end{array}$ & $\begin{array}{l}94.48 \pm 2.16 \\
92.63 \pm 3.06 \\
93.88 \pm 2.72\end{array}$ & ns & $\mathrm{p}=0.8$ & $\mathrm{p}=0.05$ \\
\hline $\mathrm{FEV}_{1}(1 / \mathrm{sec})$ & $\begin{array}{ll}\text { T } & 0 \\
\text { T } 4 \\
\text { T } 12 \\
\end{array}$ & $\begin{array}{l}0.80 \pm 0.20 \\
0.74 \pm 0.21 \\
0.71 \pm 0.20\end{array}$ & ns & $\mathrm{ns}$ & $\begin{array}{ll}\text { T } & 0 \\
\text { T } 4 \\
\text { T } 12 \\
\end{array}$ & $\begin{array}{l}0.79 \pm 0.42 \\
0.79 \pm 0.42 \\
0.75 \pm 0.36\end{array}$ & ns & $\mathrm{p}=0.5$ & $\mathrm{p}=0.6$ \\
\hline $\mathrm{FEV}_{1} / \mathrm{FVC}(\%)$ & $\begin{array}{ll}\text { T } 0 \\
\text { T } 4 \\
\text { T } 12 \\
\end{array}$ & $\begin{array}{c}37.7 \pm 11.59 \\
37.3 \pm 13.1 \\
35.8 \pm 10.43 \\
\end{array}$ & $\mathrm{~ns}$ & ns & $\begin{array}{ll}\text { T } & 0 \\
\text { T } 4 \\
\text { T } 12 \\
\end{array}$ & $\begin{array}{l}39.49 \pm 7.47 \\
93.37 \pm 7.32 \\
39.06 \pm 7.62 \\
\end{array}$ & ns & $\mathrm{p}=0.7$ & $\mathrm{p}=0.8$ \\
\hline Lactate $(\mu \mathrm{mol} / \mathrm{l})$ & $\begin{array}{ll}\text { T } 0 \\
\text { T } 4 \\
\text { T } 12 \\
\end{array}$ & $\begin{array}{l}1.70 \pm 0.33 \\
1.77 \pm 0.41 \\
1.92 \pm 0.42\end{array}$ & ns & $\mathrm{ns}$ & $\begin{array}{ll}\text { T } 1 \\
\text { T } 4 \\
\text { T } 12 \\
\end{array}$ & $\begin{array}{c}1.52 \pm 0.83 \\
1.3 \pm 0.43 \\
1.17 \pm 0.7\end{array}$ & $\mathrm{~ns}$ & $\mathrm{p}=0.02$ & $\mathrm{p}=0.06$ \\
\hline FFM (Kg) & $\begin{array}{ll}\text { T } 0 \\
\text { T } 4 \\
\text { T } 12 \\
\end{array}$ & $\begin{array}{c}35.80 \pm 5 \\
39.9 \pm 3 \\
39.6 \pm 2.5\end{array}$ & $\mathrm{~ns}$ & ns & $\begin{array}{ll}\text { T } 0 \\
\text { T } 4 \\
\text { T } 12 \\
\end{array}$ & $\begin{array}{c}40.2 \pm 4.23 \\
41.42 \pm 4.74 \\
43.86 \pm 4.76 \\
\end{array}$ & ns & $\mathrm{p}=0.04$ & $\mathrm{p}=0.04$ \\
\hline BW (Kg) & $\begin{array}{ll}\text { T } & 0 \\
\text { T } 4 \\
\text { T } 12 \\
\end{array}$ & $\begin{array}{c}54.3 \pm 7 \\
53.2 \pm 6.92 \\
52.41 \pm 6.1 \\
\end{array}$ & ns & $\mathrm{ns}$ & $\begin{array}{ll}\text { T } & 0 \\
\text { T } 4 \\
\text { T } 12 \\
\end{array}$ & $\begin{array}{c}53.32 \pm 6.74 \\
55.25 \pm 8.65 \\
58.85 \pm 10.21\end{array}$ & ns & $\mathrm{p}=0.001$ & $\mathrm{p}=0.005$ \\
\hline LBMI $\left(\mathrm{Kg} / \mathrm{m}^{2}\right)$ & $\begin{array}{ll}\text { T } 0 \\
\text { T } 4 \\
\text { T } 12 \\
\end{array}$ & $\begin{array}{c}14.8 \pm 2.3 \\
14.86 \pm 2.03 \\
14.78 \pm 1.93 \\
\end{array}$ & $\mathrm{~ns}$ & ns & $\begin{array}{ll}\text { T } & 0 \\
\text { T } 4 \\
\text { T } 12 \\
\end{array}$ & $\begin{array}{l}15.18 \pm 2.22 \\
15.54 \pm 1.73 \\
16.52 \pm 2.51 \\
\end{array}$ & ns & $\mathrm{p}=0.06$ & $\mathrm{p}=0.1$ \\
\hline $\mathrm{BMI}\left(\mathrm{Kg} / \mathrm{m}^{2}\right)$ & $\begin{array}{ll}\text { T } 0 \\
\text { T } 4 \\
\text { T } 12 \\
\end{array}$ & $\begin{array}{c}20.1 \pm 2 \\
19.89 \pm 1.82 \\
19.79 \pm 1.89 \\
\end{array}$ & $\mathrm{~ns}$ & $\mathrm{~ns}$ & $\begin{array}{ll}\text { T } & 0 \\
\text { T } 4 \\
\text { T } 12 \\
\end{array}$ & $\begin{array}{l}19.95 \pm 1.63 \\
20.61 \pm 2.54 \\
22.05 \pm 2.88 \\
\end{array}$ & $\mathrm{~ns}$ & $\mathrm{p}=0.003$ & $\mathrm{p}=0.005$ \\
\hline $\begin{array}{l}\text { Serum total proteins } \\
(\mathrm{g} / \mathrm{l})\end{array}$ & $\begin{array}{ll}\text { T } 0 \\
\text { T } 4 \\
\text { T } 12 \\
\end{array}$ & $\begin{array}{l}61.46 \pm 5.25 \\
60.24 \pm 5.27 \\
60.83 \pm 5.22 \\
\end{array}$ & ns & $\mathrm{ns}$ & $\begin{array}{l}\text { T } 0 \\
\text { T4 } \\
\text { T } 12\end{array}$ & $\begin{array}{l}61.95 \pm 2.86 \\
63.58 \pm 4.16 \\
64.75 \pm 3.77\end{array}$ & $\mathrm{~ns}$ & $\mathrm{p}=0.05$ & $\mathrm{p}=0.2$ \\
\hline Serum albumin $(g / l)$ & $\begin{array}{ll}\text { T } 0 \\
\text { T } 4 \\
\text { T } 12 \\
\end{array}$ & $\begin{array}{l}33.05 \pm 2.91 \\
32.38 \pm 3.63 \\
33.17 \pm 4.59 \\
\end{array}$ & ns & ns & $\begin{array}{ll}\text { T } & 0 \\
\text { T } 4 \\
\text { T } 12 \\
\end{array}$ & $\begin{array}{l}32.73 \pm 3.97 \\
34.93 \pm 3.81 \\
37.01 \pm 3.16 \\
\end{array}$ & $\mathrm{p}=0.005$ & $\mathrm{p}=0.004$ & $\mathrm{p}<0.001$ \\
\hline $\begin{array}{l}\text { Muscle strength } \\
\text { (handgrip) }(\mathrm{Kg})\end{array}$ & $\begin{array}{ll}\text { T } 0 \\
\text { T } 4 \\
\text { T } 12 \\
\end{array}$ & $\begin{array}{l}22.1 \pm 1.9 \\
21.9 \pm 2.3 \\
21.5 \pm 1.7 \\
\end{array}$ & $\mathrm{~ns}$ & ns & $\begin{array}{ll}\text { T } & 0 \\
\text { T } 4 \\
\text { T } 12 \\
\end{array}$ & $\begin{array}{l}21.6 \pm 1.36 \\
22.1 \pm 1.4 \\
23.2 \pm 1.6 \\
\end{array}$ & ns & $\mathrm{p}=0.05$ & $\mathrm{p}<0.01$ \\
\hline Steps $\left(n^{\circ}\right)$ & $\begin{array}{ll}\text { T } 0 \\
\text { T } 4 \\
\text { T } 12 \\
\end{array}$ & $\begin{array}{c}609.70 \pm 454.8 \\
651.83 \pm 557.96 \\
562.77 \pm 601.95 \\
\end{array}$ & ns & $\mathrm{ns}$ & $\begin{array}{ll}\text { T } & 0 \\
\text { T } 4 \\
\text { T } 12 \\
\end{array}$ & $\begin{array}{c}638.68 \pm 662.1 \\
880 \pm 836.9 \\
1140.33 \pm 524.69 \\
\end{array}$ & $\mathrm{~ns}$ & $\mathrm{p}=0.02$ & $\mathrm{p}=0.003$ \\
\hline $\begin{array}{l}\text { Energy expenditure } \\
\text { (Kcal/step/FFM Kg) }\end{array}$ & $\begin{array}{ll}\text { T } 0 \\
\text { T } 4 \\
\text { T } 12 \\
\end{array}$ & $\begin{array}{c}1.27 \pm 0.59 \\
1.26 \pm 0.7 \\
0.89 \pm 0.52 \\
\end{array}$ & $\mathrm{~ns}$ & $\mathrm{p}<0.05$ & $\begin{array}{ll}\text { T } & 0 \\
\text { T } 4 \\
\text { T } 12 \\
\end{array}$ & $\begin{array}{c}1.3 \pm 0.75 \\
1.9 \pm 0.85 \\
3.2 \pm 1.7 \\
\end{array}$ & $\mathrm{p}<0.03$ & $\mathrm{p}<0.005$ & $\mathrm{p}<0.001$ \\
\hline MMSE (score) & $\begin{array}{ll}\text { T } 0 \\
\text { T } 4 \\
\text { T } 12 \\
\end{array}$ & $\begin{array}{c}20.08 \pm 3.72 \\
19.5 \pm 3.79 \\
19.33 \pm 3.88 \\
\end{array}$ & $\mathrm{~ns}$ & $\mathrm{~ns}$ & $\begin{array}{ll}\text { T } & 0 \\
\text { T } 4 \\
\text { T } 12 \\
\end{array}$ & $\begin{array}{c}18.92 \pm 4.8 \\
18.79 \pm 4.1 \\
20.54 \pm 4.12 \\
\end{array}$ & $\mathrm{~ns}$ & $\mathrm{p}=0.02$ & $\mathrm{p}=0.02$ \\
\hline SGRQ (score) & $\begin{array}{l}\text { T } 0 \\
\text { T } 4 \\
\text { T } 12\end{array}$ & $\begin{array}{c}71.31 \pm 7.28 \\
- \\
72.79 \pm 7.3\end{array}$ & ns & ns & $\begin{array}{l}\text { T } 0 \\
\text { T } 4 \\
\text { T } 12\end{array}$ & $\begin{array}{c}72.04 \pm 8.62 \\
- \\
69.35 \pm 9.51\end{array}$ & ns & $\mathrm{p}<0.01$ & $\mathrm{p}<0.001$ \\
\hline
\end{tabular}

Data are expressed as mean \pm standard deviation.

Statistical analysis: Anova test.

$\mathrm{T} 0=$ baseline; $\mathrm{T} 4$ = after 1 months; $\mathrm{T} 12=$ after 3 months; EAA group = essential amino acid supplemented group; $\mathrm{PaO}_{2}=$ artial pressure of oxygen; $\mathrm{PaCO}_{2}=$ Partial pressure of carbon dioxide; $\mathrm{sO}_{2}=$ oxygen saturation; $\mathrm{FEV}_{1}=$ forced expiratory volume $;$ FVC = forced vital capacity; FFM = fat-free mass; BW = body weight; LBMI = Lean Body Mass Index; BMI = Body Mass Index; MMSE = Mini Mental State Examination test; SGRQ = St.George's Respiratory Questionnaire .

$\mathrm{nv}=$ normal value, $\mathrm{ns}=$ not significant. 
high improvement in energy developed during daily physical activity, and normalized for lean body mass in EAAs supplemented patients. Interestingly, the opposite occurred in subjects assuming placebo in which muscle energy expenditure worsened over time. Third, a diminished cellular acidosis lowers the rate of both somatic and myofibrillar proteolysis [43] otherwise primed by a low intracellular $\mathrm{pH}$.

The biochemical mechanisms by which EAAs lead to a better balance between the anaerobic and the aerobic muscle metabolism are based on the evidence that these can be used directly in aerobic cycles as fuel alternative to glucose [44] and, indirectly, because they shift the lactate pyruvate reaction towards the pyruvate formation [44]. This mechanism is relevant to COPD patients because it also allows them to partially overcome the block of glucose aerobic oxidation from high levels of pro-inflammatory cytokines [39].

Interestingly, EAAs-induced changes in muscle-liver metabolism anticipate the changes in body composition, thus suggesting that these rely on improved muscle-liver axisis. In other words, the limited lactate processing spares energy which becomes more available for protein synthesis.

\section{b) EAAs and quality of life}

Patients assuming EAAs also improved the subjective perception of their own health status. It is important to note that this was achieved at home, such as excluding any effect due to a better care delivered in specifically organised settings [45].

In addition the optimisation of quality of life may be due to an improved nutritional status [46, 47] and muscle strength [25]; whole body anabolic process; higher saturation of oxygen; increased physical activity of daily living [25], and reduced cognitive dysfunction [25]. Despite the high prevalence in COPD subjects [48, 49], cognitive dysfunction is often underestimated in clinical practice, and an altered cognition may reflect the pulmonary dysfunction [48] and/or hyposaturation of oxygen $[50,51]$. The improvement of saturation of oxygen can contribute to reduce cognitive dysfunction [8], while EAAs may directly influence cognition as several amino acids are precursors of brain neurotransmitters [8].

Due to a better perception of their own health status, patients can have a better adherence to pharmacological treatments which can contribute to symptom control or minimisation [52], and a possible reduction of hospitalisations [26].

In conclusion, data from the present study shows that the simple supplementation of essentials amino acids to severe sarcopenic COPD patients living at home and not admitted to any rehab program may improve both their physical autonomy and quality of life, thus surrogating the effect of a Rehab course.

From a clinical perspective, this study confirms data obtained in previous investigations carried out in patients with COPD [8, 9] or with chronic heart failure [10] who were supplemented with the same amino acid formula, at the same dose used in the present study. EAAs should not be intended as a substitute for Rehab whenever possible. EAAs may rather be used in those patients who, for any reason, cannot undergo Rehab or do not tolerate any intensive physical training due to their severe co-morbidities or frailty. In patients with more severe forms of COPD, EAAs may induce better nutritional-metabolic conditions allowing patients to initiate a program of exercise training.

Further research is needed to assess whether or not EAAs supplemented to subjects on Rehab could enhance programme effects and/or keep them at home for longer [3].

The present study has several limitations. The patients' physical performance was not documented by standardised methods (i.e. exercising on a treadmill or on a stationary bicycle) that would have allowed us to quantify both the power and the work load, and to analyse at the same time oxygen consumption and carbon dioxide concentration in expiratory flow. This information would have allowed us to better understand the mechanisms for the gain in physical performance.

Measurements of blood lactic acid during and/or after exercise would have highlighted muscle metabolic changes associated with EAAs. Small differences in body/muscle nutritionalmetabolic changes were not analyzed because of the limited sample size. Moreover, patients were not investigated after the end of the protocol, so we were not able to assess the persistence of EAAs effects. Further specific researches are needed in order to focusing these aspects.

\section{References}

1. Viegi G, Pedreschi M, Pistelli F, et al. Prevalence of airways obstruction in a general population: European Respiratory Society vs American Thoracic Society definition. Chest 2000 May; 117 (5 Suppl 2): 339S-45S.

2. Dal Negro RW, Tognella S, M, et al. Costs of chronic obstructive pulmonary disease (COPD) in Italy: the SIRIO study (social impact of respiratory integrated outcomes). Respir Med 2008; 102: 92-101.

3. Ries AL, Bauldoff GS, Carlin BW, et al. Pulmonary Rehabilitation: Joint ACCP/AACVPR Evidence-Based Clinical Practice Guidelines. Chest 2007 May; 131 (5 Suppl): 4S-42S.

4. Lacasse Y, Brosseau L, Milne S, et al. Pulmonary rehabilitation for chronic obstructive pulmonary disease. Cochrane Database Syst Rev. 2002; (3): CD003793. Review. Update in: Cochrane Database Syst Rev. 2006; (4): CD003793.

5. Garcia-Aymerich J, Farrero E, Félez MA, Risk factors of readmission to hospital for a COPD exacerbation: a prospective study. Thorax 2003; 58: 100-5.

6. Griffiths TL, Phillips CJ, Davies S, et al. Cost effectiveness of an outpatient multidisciplinary pulmonary rehabilitation programme. Thorax 2001; 56: 779-84.

7. Liu Z, Barrett EJ. Human protein metabolism: its measurement and regulation. Am $J$ Physiol Endocrinol Metab 2002; 283: E1105-12.

8. Dal Negro RW, Aquilani R, Bertacco S, et al. Comprehensive effects of supplemented essential amino acids in patients with severe COPD and sarcopenia. Monaldi Arch Chest Dis 2010; 73: 25-33. 
9. Baldi S, Aquilani R, Pinna GD, et al. Fat-free mass change after nutritional rehabilitation in weight losing COPD: role of insulin, C-reactive protein and tissue hypoxia. Int J Chron Obstruct Pulmon Dis 2010; 5: 29-39.

10. Aquilani R, Opasich C, Gualco A et al. Adequate energyprotein intake is not enough to improve nutritional and metabolic status in muscle-depleted patients with chronic heart failure. Eur J Heart Fail 2008; 10: 1127-35.

11. Fernstrom JD. Role of precursor availability in control of monoamine biosynthesis in brain. Physiol Rev 1983; 63: 484-546.

12. Agranoff BW, Cotman CW, Uhler MD. Learning and memory. In: Siegel GJ, Agranoff BW, Albers RW, Fisher SK, Uhler MD. (eds) Basic Neurochemistry. Philadelphia, PA: Lippincott Raven, 1998; 1028-1050.

13. Langer D, Gosselink R, Sena R, Burtin C, et al. Validation of two activity monitors in patients with COPD. Thorax 2009; 64: 641-2.

14. Wilson DO, Rogers RM, Wright EC, Anthonisen NR. Body weight in chronic obstructive pulmonary disease. The National Institutes of Health Intermittent PositivePressure Breathing Trial. Am Rev Respir Dis 1989; 139: $1435-8$.

15. Vandenbergh E, Van de Woestijne KP, Gyselen A. Weight changes in the terminal stages of chronic obstructive pulmonary disease. Relation to respiratory function and prognosis. Am Rev Respir Dis 1967; 95: 556-66.

16. Steiner MC, Barton RL, Singh SJ, Morgan MD. Bedside methods versus dual energy X-ray absorptiometry for body composition measurement in COPD. Eur Respir J 2002; 19: 626-31.

17. Baarends EM, Schols AM, Mostert R, Wouters EF. Peak exercise response in relation to tissue depletion in patients with chronic obstructive pulmonary disease. Eur Respir J 1997; 10: 2807-13.

18. Aquilani R, Opasich C, Verri M, et al. Is nutritional intake adequate in chronic heart failure patients? $J \mathrm{Am}$ Coll Cardiol 2003 1; 42: 1218-23.

19. Istituto Nazionale della Nutrizione; 1989. Tabelle di composizione degli alimenti.

20. Aquilani R, Tramarin R, Pedretti RF, et al. Despite good compliance, very low fat diet alone does not achieve recommended cholesterol goals in outpatients with coronary heart disease. Eur Heart $J$ 1999; 20: 1020-9.

21. Campbell WW, Trappe TA, Wolfe RR, Evans WJ. The recommended dietary allowance for protein may not be adequate for older people to maintain skeletal muscle. $J$ Gerontol A Biol Sci Med Sci 2001; 56: M373-80.

22. Spijkerman D C, Snijders C J, Stijnen T, Lankhorst G J. Standardization of grip strength measurements. Effects on repeatability and peak force. Scand J Rehabil Med 1991; 23: 203-6.

23. Bergmeyer HU, Passoneau JV, Lowry OH. Lactate. In: Bergmeyer H.U., editor. Methods of enzymatic analysis. 2nd ed. New York: Academic Press; 1988. p. 14461450.

24. Folstein MF, Folstein SE, McHugh PR. "Mini-mental state". A practical method for grading the cognitive state of patients for the clinician. J Psychiatr Res 1975; 12: 189-98.

25. Hickson M, Frost G. An investigation into the relationships between quality of life, nutritional status and physical function. Clin Nutr 2004; 23: 213-21.

26. Pitta F, Troosters T, Probst VS, et al. Physical activity and hospitalization for exacerbation of COPD. Chest 2006; 129: 536-44.

27. Engelen MP, Schols AM, Baken WC, Wesseling GJ, et $a l$. Nutritional depletion in relation to respiratory and peripheral skeletal muscle function in out-patients with COPD. Eur Respir J 1994; 7: 1793-7.
28. Schols AM, Buurman WA, Staal van den Brekel AJ, et $a l$. Evidence for a relation between metabolic derangements and increased levels of inflammatory mediators in a subgroup of patients with chronic obstructive pulmonary disease. Thorax 1996; 51: 819-24.

29. Pitsiou G, Kyriazis G, Hatzizisi O, et al. Tumor necrosis factor-alpha serum levels, weight loss and tissue oxygenation in chronic obstructive pulmonary disease. Respir Med 2002; 96: 594-8.

30. Scognamiglio R, Testa A, Aquilani R, et al. Impairment in walking capacity and myocardial function in the elderly: is there a role for non pharmacologic therapy with nutritional amino acid supplements? Am J Cardiol 2008; 101 (11A): 78E-81E.

31. Kimball SR, Fabian JR, Pavitt GD, et al. Regulation of guanine nucleotide exchange through phosphorylation of eukaryotic initiation factor eIF2alpha. Role of the alpha- and delta-subunits of eiF2b. J Biol Chem 1998; 273: 12841-5.

32. Wang X, Campbell LE, Miller CM, Proud CG. Amino acid availability regulates p70 S6 kinase and multiple translation factors. Biochem J 1998; 334: 261-7.

33. Jousse C, Bruhat A, Ferrara M, Fafournoux P. Physiological concentration of amino acids regulates insulin like-growth-factor-binding protein 1 expression. Biochem $J$ 1998; 334 (Pt 1): 147-53.

34. Dillon EL, Sheffield-Moore M, Paddon-Jones D, et al. Amino acid supplementation increases lean body mass, basal muscle protein synthesis, and insulin-like growth factor-I expression in older women. J Clin Endocrinol Metab 2009; 94: 1630-7.

35. Volpi E, Ferrando AA, Yeckel CW, et al. Exogenous amino acids stimulate net muscle protein synthesis in the elderly. J Clin Invest 1998; 101: 2000-7.

36. Creutzberg EC, Casaburi R. Endocrinological disturbances in chronic obstructive pulmonary disease. Eur Respir J Suppl 2003; 46: 76s-80s.

37. Creutzberg EC, Wouters EF, Mostert R, et al. Efficacy of nutritional supplementation therapy in depleted patients with chronic obstructive pulmonary disease. $\mathrm{Nu}$ trition 2003; 19: 120-7.

38. Weisberg $\mathrm{J}$, Wanger $\mathrm{J}$, Olson $\mathrm{J}$, et al. Megestrol acetate stimulates weight gain and ventilation in underweight COPD patients. Chest 2002; 121: 1070-8

39. Vary TC, O'Neill P, Cooney RN, et al. Chronic infusion of interleukin 1 induces hyperlactatemia and altered regulation of lactate metabolism in skeletal muscle. J Parenter Enteral Nutr 1999; 23: 213-7.

40. Xia Y, Warshaw JB, Haddad GG. Effect of chronic hypoxia on glucose transporters in heart and skeletal muscle of immature and adult rats. Am J Physiol 1997; 273 (5 Pt 2): R1734-41.

41. Pastoris O, Dossena M, Foppa P, et al. Modifications by chronic intermittent hypoxia and drug treatment on skeletal muscle metabolism. Neurochem Res 1995; 20: 143-50.

42. Terjung RL, Dudley GA, Meyer RA. Metabolic and circulatory limitations to muscular performance at the organ level. J Exp Biol 1985; 115: 307-18.

43. Mitch WE, Goldberg AL. Mechanisms of muscle wasting. The role of the ubiquitin-proteasome pathway. $N$ Engl J Med 1996; 335: 1897-905.

44. Lehninger AL, Nelson DL, Cox MM. In: Zanichelli, editor. Principi di Biochimica 2nd ed.: 1994.

45. Brajković L, Godan A, Godan L. Quality of life after stroke in old age: comparison of persons living in nursing home and those living in their own home. Croat Med J 2009; 50: 182-8.

46. Tidermark J, Zethraeus N, Svensson O, et al. Femoral neck fractures in the elderly: functional outcome and quality of life according to euroqol. Qual Life Res 2002; 11: 473-481. 
47. Mackenzie AE, Chang AM. Predictors of quality of life following stroke. Disabil Rehabil 2002; 24: 259-265.

48. Hung WW, Wisnivesky JP, Siu AL, Ross JS. Cognitive decline among patients with chronic obstructive pulmonary disease. Am J Respir Crit Care Med 2009; 180: 134-7.

49. Isoaho R, Puolijoki H, Huhti E, et al. Chronic obstructive pulmonary disease and cognitive impairment in the elderly. Int Psychogeriatr 1996; 8: 113-25.

50. Ortapamuk H, Naldoken S. Brain perfusion abnormalities in chronic obstructive pulmonary disease: compar- ison with cognitive impairment. Ann Nucl Med 2006; 20: 99-106.

51. Incalzi RA, Gemma A, Marra $\mathrm{C}$, et al. Chronic obstructive pulmonary disease. An original model of cognitive decline. Am Rev Respir Dis 1993; 148: 418-24.

52. Gutteling JJ, Darlington AS, Janssen HL, et al. Effectiveness of health-related quality-of-life measurement in clinical practice: a prospective, randomized controlled trial in patients with chronic liver disease and their physicians. Qual Life Res 2008; 17: 195-205.

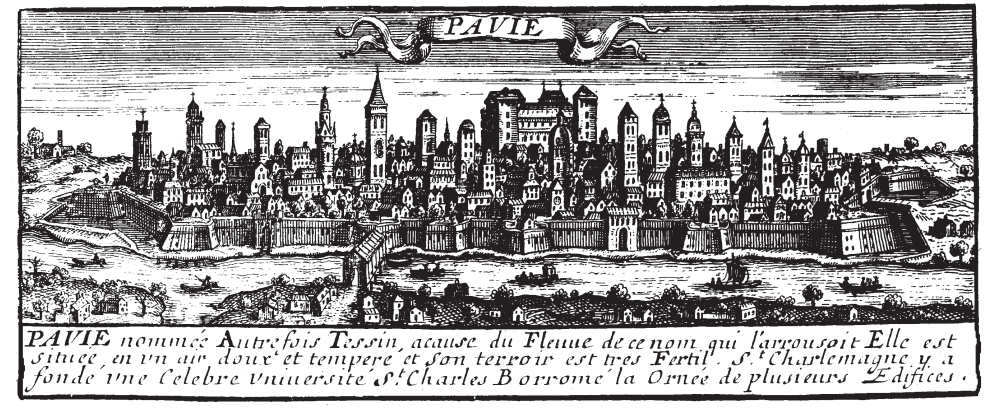

